\title{
Status of Provisions of the Factories Act, 1948 - A study at Penna Cement Industries Limited (PCIL), Tadipatri.
}

\author{
Keerthi Sriya $\mathrm{A}^{1,}$ Dr. Panatula Murali Krishna ${ }^{2}$ \\ ${ }^{1}$ Research Scholar, Department of Management, JNTU, Anantapur, Andhra Pradesh, India 515003, \\ ${ }^{2}$ Professor in the Dept. of Management (SKIM), SK University, Andhra Pradesh, India 515003,
}

\begin{abstract}
This research paper focus on exploring the status of awareness \& satisfactory levels of various provisions of Indian Factories act, 1948 in the target organisation 'Penna Cement Industries Limited' located at Tadipatri in Anantapur district of Andhra Pradesh. The paper initially describes the background of Labour Legislation in India and its classification. The need, importance and objectives of the research is than stated followed by the Literature review that briefs the important provisions of the Factories Act pertaining to Labour and the Industry \& Company profile where the research is conducted.

The research targets to know the awareness and satisfactory levels of the provisions of Factories act among the lower class of employees by taking a sample of 50 employees by Random Sampling method from the total population of lower class of employees in the organisation. The primary data collected through the Interviewing and Questionnaires. The questionnaire was made as simple as possible and where required it was read out \& explained in the local language to many of the employees by the researcher because the majority of the sample population were not well educated. The secondary data was collected through various company publications like Annual Reports, Files and documents related to labour welfare and books, journals, research articles related to Factories Act, 1948.

The results indicate that the overall awareness levels of the various provisions of the Factories Act, 1948 is not very high but the satisfactory levels with the facilities provided by the organisation seems to be adequate among the sample employees. In simple words, though the sample employees are not very much aware of the facilities they are to be provided by the Factories Act, 1984, they are being provided with adequate health. Safety \& welfare measured by the organisation which is keeping the employees satisfied.
\end{abstract}

Keywords: Labour Legislation, Factories Act, 1948, Health, Safety, Welfare, Awareness, Satisfaction Levels

\section{Introduction}

India's Labour Policy is mainly based on Labour Laws. The labour laws of independent India derive their origin, inspiration and strength partly from the views expressed by important nationalist leaders during the days of national freedom struggle, partly from the debates of the Constituent Assembly and partly from the provisions of the Constitution and the International Conventions and Recommendations. The relevance of the dignity of human labour and the need for protecting and safeguarding the interest of labour as human beings has been enshrined in Chapter-III (Articles 16, 19, 23 \& 24) and Chapter IV (Articles 39, 41, 42, 43, 43A \& 54) of the Constitution of India keeping in line with Fundamental Rights and Directive Principles of State Policy. The Labour Laws were also influenced by important human rights and the conventions and standards that have emerged from the United Nations. These include right to work of one's choice, right against discrimination, prohibition of child labour, just and humane conditions of work, social security, protection of wages, redress of grievances, right to organize and form trade unions, collective bargaining and participation in management. Our labour laws have also been significantly influenced by the deliberations of the various Sessions of the Indian Labour Conference and the International Labour Conference. Labour legislations have also been shaped and influenced by the recommendations of the various National Committees and Commissions such as First National Commission on Labour (1969) under the Chairmanship of Justice Gajendragadkar, National Commission on Rural Labour (1991), Second National Commission on Labour (2002) under the Chairmanship of Shri Ravindra Varma etc. and judicial pronouncements on labour related matters specifically pertaining to minimum wages, bonded labour, child labour, contract labour etc.

LABOUR LAWS in India are broadly classified as -

1. Laws related to Industrial Relations

2. Laws related to Wages

3. Laws related to Working Hours, Conditions of Service and Employment

4. Laws related to Equality and Empowerment of Women

5. Laws related to Deprived and Disadvantaged Sections of the Society

6. Laws related to Social Security 
The Factories Act, 1948 fall in the third category of Labour Laws - Laws related to Working Hours, Conditions of Service and Employment. The objective of the Act is to ensure adequate safety measures and to promote the health and welfare of the workers employed in factories and to prevent haphazard growth of factories through the provisions related to the approval of plans before the creation of a factory. The Act is applicable to the whole of India including Jammu \& Kashmir. The act covers all manufacturing processes and establishments falling within the definition of 'factory' and is applicable to all factories using power and employing 10 or more workers, and if not using power, employing 20 or more workers on any day of the preceding 12 months. The Act consists of 120 Sections and 3 Schedules. Schedule 1 contains list of industries involving hazardous processes. Schedule 2 is about permissible level of certain chemical substances in work environment. Schedule 3 consists of list of notifiable diseases.

\section{a. Objectives of the Study}

a) To study the awareness of Various provisions under the Factories Act, 1948 pertaining to Labour among the sample employees at Penna Cements, Tadipatri

b) To excavate the level of satisfaction about the implementation of various provisions under the Factories Act , 1948 pertaining to Labour among the sample employees at Penna Cements, Tadipatri

\section{b. Need and importance of the study}

Amongst the present generation teenagers, Software career is the most sought out one. It is not very surprising to know that out of any 10 students randomly chosen in any Indian city and asked a question 'Will you be interested to work in a Cement Industry when you grow up?', many a times all the ten students would stare at the interviewer and would answer a big NO. The biggest reason being the very negative impression the todays teens have regarding the work environments that prevails in such production industries. It is widely believed that the basic amenities are not being provided to the workers at such production industries.

If the above scenario is not curtailed immediately, there may be a vacuum of quality labour in such industries and these industries would be forced to employ only the least quality labour available in the market.

The need of the study is to find out the present status of awareness and satisfaction of the various provisions of the Factories Act, 1948 in order to excavate the gaps that are to be filled in near future.

The importance of this study is that it can play a very crucial role in filling the gaps to improve the picture of the prevailing working conditions of the labour in the production industries.

\section{c. Scope of the Study}

The study essentially focus on knowing the awareness of Various provisions under the Factories Act, 1948 pertaining to Labour and to excavate the level of satisfaction about the implementation of various provisions under the Factories Act , 1948 pertaining to Labour among the sample employees at Penna Cements, Tadipatri. The study covers mainly the lower class of employees employed at Penna Cements, Tadipatri.

\section{a. The Factories Act, 1948 - Important Provisions in a gist}

\section{Literature Review}

\section{Facilities and Conveniences -}

The factory should be kept clean. [Section 11]. There should be arrangement to dispose of wastes and effluents. [Section 12]. Ventilation should be adequate. Reasonable temperature for comfort of employees should be maintained. [Section 13]. Dust and fumes should be controlled below permissible limits. [Section 14]. Artificial humidification should be at prescribed standard level. [Section 15]. Overcrowding should be avoided. [Section 16]. Adequate lighting, drinking water, latrines, urinals and spittoons should be provided. [Sections 17 to 19]. Adequate spittoons should be provided. [Section 20].

\section{Welfare -}

Adequate facilities for washing, sitting, storing clothes when not worn during working hours. [Section 42]. If a worker has to work in standing position, sitting arrangement to take short rests should be provided. [Section 44]. Adequate First aid boxes should be provided and maintained [Section 45].

\section{Facilities in case of large factories -}

Following facilities are required to be provided by large factories - Ambulance room if 500 or more workers are employed; Canteen if 250 or more workers are employed. It should be sufficiently lighted and ventilated and suitably located. [Section 46]. Rest rooms / shelters with drinking water when 150 or more 
workmen are employed [Section 47]; Crèches if 30 or more women workers are employed. [Section 48]; Full time Welfare Officer if factory employs 500 or more workers [Section 49]; Safety Officer if 1,000 or more workmen are employed.

\section{Safety -}

All machinery should be properly fenced to protect workers when machinery is in motion. [Section 21 to 27]. Hoists and lifts should be in good condition and tested periodically. [Section 28 and 29]. Pressure plants should be checked as per rules. [Section 31]. Floor, stairs and means of access should be of sound construction and free form obstructions. [Section 32]. Safety appliances for eyes, dangerous dusts, gas, and fumes should be provided. [Sections 35 and 36]. Worker is also under obligation to use the safety appliances. He should not misuse any appliance, convenience or other things provided. [Section 111]. In case of hazardous substances, additional safety measures have been prescribed. [Sections $41 \mathrm{~A}$ to $41 \mathrm{H}$ ]. Adequate firefighting equipment should be available. [Section 38]. Safety Officer should be appointed if number of workers in factory are 1,000 or more. [Section 40B].

\section{Working Hours -}

A worker cannot be employed for more than 48 hours in a week. [Section 51]. Weekly holiday is compulsory. If he is asked to work on weekly holiday, he should have full holiday on one of three days immediately or after the normal day of holiday. [Section 52(1)]. He cannot be employed for more than 9 hours in a day. [Section 54]. At least half an hour rest should be provided after 5 hours. [Section 55]. Total period of work inclusive of rest interval cannot be more than 10.5 hours. [Section 56]. A worker should be given a weekly holiday. Overlapping of shifts is not permitted. [Section 58]. Notice of period of work should be displayed. [Section 61].

\section{Overtime Wages -}

If a worker works beyond 9 hours a day or 48 hours a week, overtime wages are double the rate of wages are payable. [Section 59(1)]. A workman cannot work in two factories. There is restriction on double employment. [Section 60]. However, overtime wages are not payable when the worker is on tour. Total working hours including overtime should not exceed 60 in a week and total overtime hours in a quarter should not exceed 50. Register of overtime should be maintained. An employee working outside the factory premises like field workers etc. on tour outside headquarters are not entitled to overtime. - R Ananthan v. Avery India 1972(42) FJR $304(\mathrm{Mad}$ HC) $*$ Director of Stores v. P S Dube 1978 Lab IC $390=52$ FJR $299=1978$ I LLN $464=36$ FLR 420.

\section{Employment of Women -}

A woman worker cannot be employed beyond the hours 6 a.m. to 7.00 pm. State Government can grant exemption to any factory or group or class of factories, but no woman can be permitted to work during $10 \mathrm{PM}$ to 5 AM. Shift change can be only after weekly or other holiday and not in between. [Section 66].

\section{Night Shift for women -}

Factories Act has been proposed to be amended to allow night shift for women workers. The Government has decided to amend Section 66 of the Factories Act, 1948 to allow employment of women workers between $7.00 \mathrm{pm}$ and $6.00 \mathrm{am}$. The demand of women's organisations and in tune with the present economic globalization, the Government has decided to bring in then required changes in the Act. This flexibility would be available to all manufacturing units including the apparel sector. This decision has been taken after meetings with the representatives of the employers and the trade unions. The proposed Bill will empower the State Governments for allowing the necessary flexibility in employment of women during night shift in factories. The proposed amendment would inter-alia provide that the employer has to ensure occupational safety and adequate protection to the women workers. However, the State Government or any person authorised by it would be allowing employment of women during night only after consulting the workers or their representative organisations and concerned employers or their representatives. The State Governments are also empowered to frame their own rules for allowing such permissions.

\section{Record of Workmen -}

A register (muster roll) of all workers should be maintained. No worker should be permitted to work unless his name is in the register. Record of overtime is also required to be maintained. [Section 62]. 


\section{Leave -}

A worker is entitled in every calendar year annual leave with wages at the rate of one day for every 20 days of work performed in the previous calendar year, provided that he had worked for 240 days or more in the previous calendar year. Child worker is entitled to one day per every 15 days. While calculating 240 days, earned leave, maternity leave upto 12 weeks and lay off days will be considered, but leave shall not be earned on those days. [Section 79]. - Leave can be accumulated upto 30 days in case of adult and 40 days in case of child. Leave admissible is exclusive of holidays occurring during or at either end of the leave period. Wage for period must be paid before leave begins, if leave is for 4 or more days. [Section 81]. Leave cannot be taken for more than three times in a year. Application for leave should not normally be refused. [These are minimum benefits. Employer can, of course, give additional or higher benefits].

\section{Wages for overtime and Leave Salary -}

Wages for leave encashment and overtime will include dearness allowance and cash equivalent of any benefit. However, it will not include bonus or overtime.

\section{Child Employment -}

Child below age of 14 should not be employed. [Section 67]. Child above 14 but below 15 years of age can be employed only for 4.5 hours per day or during the night. [Section 71]. He should be certified fit by a certifying surgeon. [Section 68]. He cannot be employed during night between $10 \mathrm{pm}$ to $6 \mathrm{am}$. [Section 71]. A person over 15 but below 18 years of age is termed as 'adolescent'. He can be employed as an adult if he has a certificate of fitness for a full day's work from certifying surgeon. An adolescent is not permitted to work between $7 \mathrm{pm}$ and $6 \mathrm{am}$. [Section 70]. There are more restrictions on employment of female adolescent. Register of child workers should be maintained. [Section 73].

\section{Display on Notice Board -}

A notice containing abstract of the Factories Act and the rules made there under, in English and local language should be displayed. Name and address of Factories Inspector and the certifying surgeon should also be displayed on notice board. [Section 108(1)].

\section{Notice of Accidents, Diseases Etc. -}

Notice of any accident causing disablement of more than 48 hours, dangerous occurrences and any worker contacting occupational disease should be informed to Factories Inspector. [Section 88]. Notice of dangerous occurrences and specified diseases should be given. [Sections 88A and 89].

\section{Obligation regarding Hazardous Processes / Substances -}

Information about hazardous substances / processes should be given. Workers and general public in vicinity should be informed about dangers and health hazards. Safety measures and emergency plan should be ready. Safety Committee should be appointed.

\section{b. Industry Profile}

India is the second largest producer of cement in the world. The production of cement in India has increased at a compound annual growth rate (CAGR) of 9.7 per cent to reach 272 million tonnes (MT) in the period 2006-2013. It is expected to touch 407 MT by 2020.

India's potential in infrastructure is vast. It has the capacity to become the world's third largest construction market by 2025, adding 11.5 million homes a year to become a US\$ 1 trillion a year market, according to a study by Global Construction Perspectives and Oxford Economics. This opens up a tremendous window of opportunity for the country's cement industry.

Notwithstanding its current position one of the leaders in cement production, India's riches in the sector remain somewhat untapped. "Lafarge's India business has been very successful and the country is among the top 10 markets globally for Lafarge. But going forward, we should rank higher because of the potential of the Indian market," says Mr Martin Kriegner, CEO of the Indian branch of the world's largest cement manufacturer, Lafarge.

\section{Market Size}

The Indian cement sector is expected to witness positive growth in the coming years, with demand set to increase at a CAGR of more than 8 per cent in the period FY 2013-14 to FY 2015-16, according to the latest report titled 'Indian Cement Industry Outlook 2016' by market research consulting firm RNCOS. The report 
further observed that India's southern region is creating the maximum demand for cement, which is expected to increase more in future.

The cement and gypsum products sector has attracted foreign direct investments (FDI) worth US\$ 2,656.29

million in the period April 2000-August 2013, according to data published by the Department of Industrial

Policy and Promotion (DIPP).

\section{Investments}

- Prism Cement Ltd has become the first Indian company to get the Quality Council of India's (QCI) certification for its ready-mix concrete (RMC) plant in Kochi, Kerala. The company received the certification from Institute for Certification and Quality Mark (ICQM), a leading Italian certification body authorised to oversee QCI compliance.

- UltraTech Cement, an Aditya Birla Group Company, has acquired the 4.8 million tonne per annum (MTPA) Gujarat unit of Jaypee Cement Corp for Rs 3,800 crore (US\$ 595.61 million).

- ACC Ltd plans to invest Rs 3,000 crore (US\$ 470.22 million) to expand its capacity by nearly 4 MT a year in three eastern region states, over the next three years.

- $\quad$ Reliance Cements Co Pvt Ltd will set up a 3 MTPA grinding unit at an estimated cost of Rs 600 crore (US\$ 94.04 million). The unit is likely to come up at Raghunathpur in Purulia, West Bengal.

- Reliance Cement Co, a special purpose vehicle (SPV) of Reliance Infrastructure Ltd, is commissioning its first 5 MTPA plant in Madhya Pradesh. The project has been implemented at a cost of approximately Rs 3,000 crore (US\$ 470.22 million).

- Zuari Cement plans to set up a cement grinding unit at Auj (Aherwadi) and Shingadgaon villages in Solapur, Maharashtra. The new unit will have a production capacity of 1 MTPA and is expected to be operational by the second quarter of 2015.

- JSW Steel has acquired Heidelberg Cement India's 0.6 MTPA cement grinding facility in Raigad, Maharashtra, for an undisclosed amount.

\section{Government Initiatives}

Giving impetus to the market, the Indian government plans to roll out public-private partnership (PPP) projects worth Rs 1 trillion (US\$ 15.67 billion) over the next six months. The Principal Secretary in the Prime Minister's Office (PMO) will monitor these projects.

Also, the steering group appointed by Dr Manmohan Singh, Prime Minister of India, to accelerate infrastructure investments, has set deadlines for the awarding of projects such as Mumbai rail corridor and Navi Mumbai Airport, among others.

The Goa State Pollution Control Board (GSPCB) has signed a memorandum of understanding (MoU) with Vasavdatta Cement, a company with its plant in Karnataka. The firm would use the plastic waste collected by the state agencies and village panchayats from Goa as fuel for its manufacturing plant.

\section{Road Ahead}

The globally-competitive cement industry in India continues to witness positive trends such as cost control, continuous technology upgradation and increased construction activities. Furthermore, major cement manufacturers in India are progressively using other alternatives such as bioenergy as fuel for their kilns. This is not only helping to bring down production costs of cement companies, but is also proving effective in reducing emissions.

With the ever-increasing industrial activities, real estate, construction and infrastructure, in addition to the various Special Economic Zones (SEZs) being developed across the country, there is a demand for cement.

It is estimated that the country requires about US\$ 1 trillion in the period FY 2012-13 to FY 2016-17 to fund infrastructure such as ports, airports and highways to boost growth, which promises a good scope for the cement industry.

\section{c. Company Profile}

Penna Cement Industriies Limited (PCIL) was formed in year 1991 by Mr. P. Prathap Reddy. First plant was commissioned in 1994 at Talaricheruvu village in Tadipatri Mandal of Ananthapur district of Andhra Pradesh with initial capacity of 0.2 mtpa.

Penna Cement Industriies Limited is an ISO 9001:2008 Company. 
Penna is well positioned for continued growth and market dominance because of its vibrant leadership. Under the able leadership of founder promoter, Mr.P.Prathap Reddy, the management has taken significant steps to renew and refresh the core business of cement manufacturing for tomorrow, making the company achieve greater heights.

\section{Vision of the Organisation}

To make the world eco-friendly, lively and safe for human civilisation

\section{Mission of the Organisation (Quality Policy)}

We are the leading manufacturer of cements. To emerge as a leader on all socio-economical fronts by delivering worth and quality through commitment to comply statutory and regulatory requirements and continually improving the effectiveness of quality management system. To provide innovative solutions to the growing challenges faced by the modern construction industry.

\section{Grades of Cement}

The Company produces the following grades of cement.

1. Penna Power - OPC 53 Grade (Ordinary Portland cement) - For quality construction and structures IS 12269

2. Penna Super - OPC 43 Grade (Ordinary Portland cement) IS 8112

3. Penna Suraksha PBFSC Grade IS 455

4. Penna Gold PPC Grade (Portland Pozzolane Cement) (Fly ash based) - For all applications where Heat and Hydrogen are required Very Low. - IS 1489

\section{Research Method}

\section{a. Population and sample}

Research population is all of the lower class employees working at the Penna Cements, Tadipatri. The research sample consists a total of 50 respondent from the population. The sampling technique used is Random Sampling.

\section{b. Data collection and analysis method}

Research data consist of Primary and Secondary data. The primary data collected through the Interviewing and Questionnaires. The questionnaire was made as simple as possible and were basically read out \& explained in the local language to many of the employees by the researcher because the majority of the sample were not much literates to understand the belong to minimum educated category. Their responses were noted by the researcher. The secondary data was collected through information \& data of Penna Cements, Tadipatri, Published magazines, journals, web articles and books.

The Questionnaire consisted of 42 questions. 7 questions to explore each of the below -

a. Awareness of Health measures in the Factories Act, 1948 amongst the sample employees

b. Satisfaction level of Health measures in the Factories Act, 1948 amongst the sample employees

c. Awareness of Safety measures in the Factories Act, 1948 amongst the sample employees

d. Satisfaction level of Safety measures in the Factories Act, 1948 amongst the sample employees

e. Awareness of Welfare measures in the Factories Act, 1948 amongst the sample employees

f. Satisfaction level of Welfare measures in the Factories Act, 1948 amongst the sample employees

Each question clearly aims at exploring any one of the above objective. The responses are collected in the form of 3-point SUMMATED LIKERT SCALE. The 3-point Scale is selected so that the results are clear and reduces unambiguous responses. The scale starts from negative response [1] to neutral response [2] to positive response [3].

The total collected Primary data consisted of altogether 2100 responses [350 responses in each category mentioned above] which were analysed using SIMPLE PERCENTILE method to derive the conclusions. The obtained percentile is then tabulated for further interpretation.

\section{Results and Interpretation}

The results indicate that the overall awareness levels of the various provisions of the Factories Act, 1948 is less but the satisfactory levels with the facilities provided by the organisation is adequate among the sample employees. Out of the above, the awareness about the Health Provisions of the Factories Act, 1948 is moderate $(43 \%)$ which is the highest of awareness among all the provisions of the Factories act, 1948. Remaining $57 \%$ of the population either gave a neutral or poor awareness indication. The awareness about the Safety Provisions of the Factories Act, 1948 is poor (27\%). Remaining 73\% of the population either gave a 
neutral or poor awareness indication. The awareness about the Welfare Provisions of the Factories Act, 1948 is moderate $(40 \%)$ which is very close to the awareness about the Health provisions. Remaining $60 \%$ of the population either gave a neutral or poor awareness indication. When the level of satisfaction is considered, the satisfaction level amongst the sample employees about the Welfare facilities provided by the organization is standing at the highest with $86 \%$. Remaining $14 \%$ of the population either gave a neutral or poor level of Satisfaction indication. The satisfaction level amongst the sample employees about the Welfare facilities provided by the organization is standing at the second position with $77 \%$. Remaining $23 \%$ of the population either gave a neutral or poor level of Satisfaction indication. The satisfaction level amongst the sample employees about the Safety facilities provided by the organization is standing at the bottom most with $63 \%$. Remaining $37 \%$ of the population either gave a neutral or poor level of Satisfaction indication.

\section{a. Awareness of Health measures in the Factories Act, 1948 amongst the sample employees}

The questionnaire that was used to collect the primary data consisted of total 7 questions that aimed to explore the Awareness of Health measures in the Factories Act, 1948 amongst the sample employees. Each question had 3 responses marked with Nos. 1 to 3 that explain the level of awareness in the ascending order from Poor [1] to Neutral [2] to Good [3]. 'Poor' responses indicate that the Awareness is INADEQUATE. 'Neutral' responses indicate that the Awareness is doubtful and uncertain. 'Good' responses indicate that the Awareness is ADEQUATE.

Tabular column Representation of the collected Data

\begin{tabular}{|l|c|c|}
\hline Awareness of Health measures in the Factories Act, 1948 & No. of Responses & Percentage \\
\hline $\begin{array}{l}\text { POOR AWARENESS } \\
\text { Negative Response, [=1 in LIKERT 3-point Scale] }\end{array}$ & 185 & $53 \%$ \\
\hline $\begin{array}{l}\text { UNCERTAIN AWARENESS } \\
\text { Neutral Response, [=2 in LIKERT 3-point Scale] }\end{array}$ & 14 & $4 \%$ \\
\hline $\begin{array}{l}\text { GOOD AWARENESS } \\
\text { Positive Response, [=3 in LIKERT 3-point Scale] }\end{array}$ & 151 & $43 \%$ \\
\hline TOTAL & $\mathbf{3 5 0}$ & $\mathbf{1 0 0 \%}$ \\
\hline
\end{tabular}

Bar Graph Representation based on Actual no. of responses

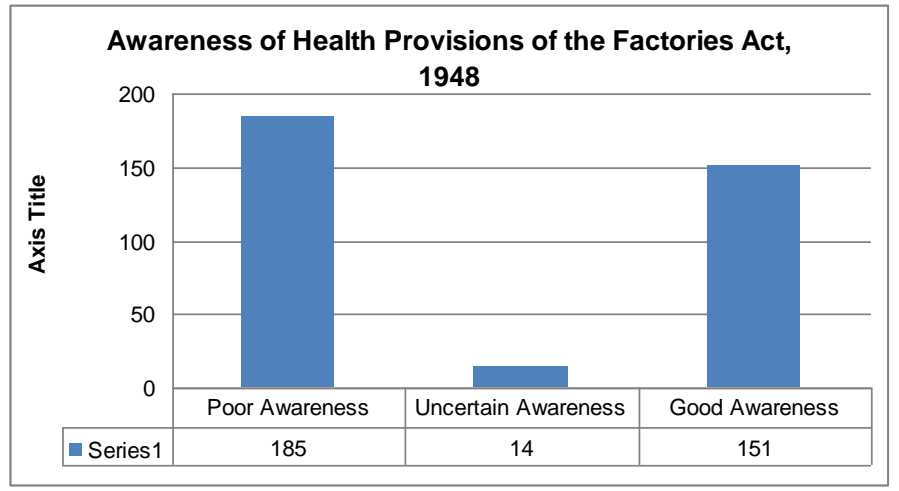

Pie Diagram Representation showing percentage in each category

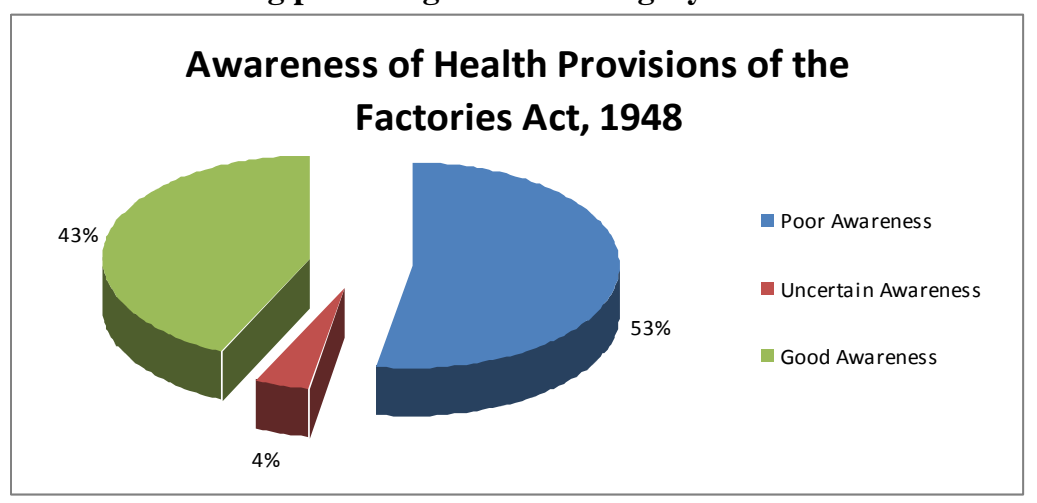




\section{Interpretation of above Data representations}

The above table shows that out of 350 responses, a total of 185 responses fall in the negative response range. On the contrary, the total no. of 151 responses fall in the positive response range. In the neutral range, there are altogether 14 responses which states that the sample employees are neither clearly aware about the provisions nor completely unaware about those. When computed to percentiles and studied, it can be seen that out of $100 \%$, a total of $53 \%$ responses fall in the negative response range. On the contrary, a total of $43 \%$ responses fall in the positive response range. In the neutral range, there are $4 \%$ responses. Hence, the above data clearly interprets that the AWARENESS about the various Health Provisions of the Factories Act, 1948 among the sample employees is overall Poor.

\section{b. Awareness of Safety measures in the Factories Act, 1948 amongst the sample employees}

The questionnaire that was used to collect the primary data consisted of total 7 questions that aimed to explore the Awareness of Safety measures in the Factories Act, 1948 amongst the sample employees. Each question had 3 responses marked with Nos. 1 to 3 that explain the level of awareness in the ascending order from Poor [1] to Neutral [2] to Good [3]. 'Poor' responses indicate that the Awareness is INADEQUATE. 'Neutral' responses indicate that the Awareness is doubtful and uncertain. 'Good' responses indicate that the Awareness is ADEQUATE.

Tabular column Representation of the collected Data

\begin{tabular}{|l|c|c|}
\hline Awareness of Safety measures in the Factories Act, 1948 & No. of Responses & Percentage \\
\hline $\begin{array}{l}\text { POOR AWARENESS } \\
\text { Negative Response, [=1 in LIKERT 3-point Scale] }\end{array}$ & 203 & $58 \%$ \\
\hline $\begin{array}{l}\text { UNCERTAIN AWARENESS } \\
\text { Neutral Response, [=2 in LIKERT 3-point Scale] }\end{array}$ & 52 & $15 \%$ \\
\hline $\begin{array}{l}\text { GOOD AWARENESS } \\
\text { Positive Response, [=3 in LIKERT 3-point Scale] }\end{array}$ & 95 & $27 \%$ \\
\hline TOTAL & $\mathbf{3 5 0}$ & $\mathbf{1 0 0 \%}$ \\
\hline
\end{tabular}

Bar Graph Representation based on Actual no. of responses

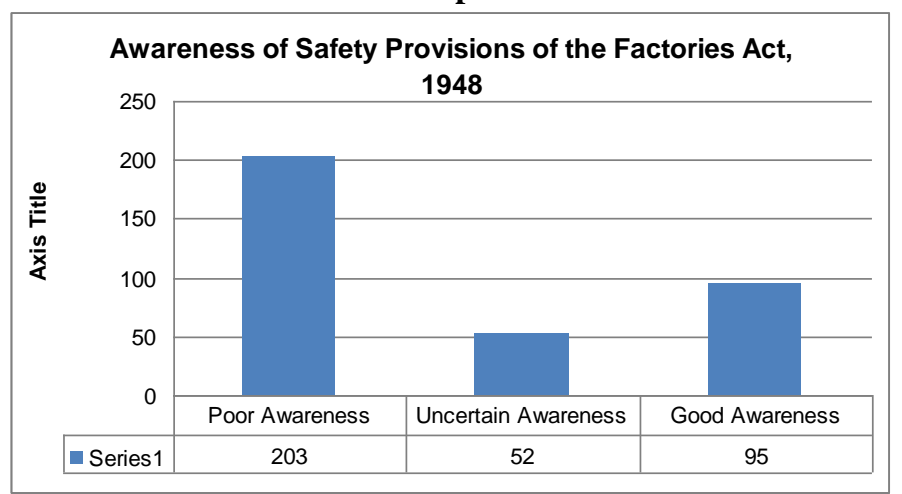

Pie Diagram Representation showing percentage in each category

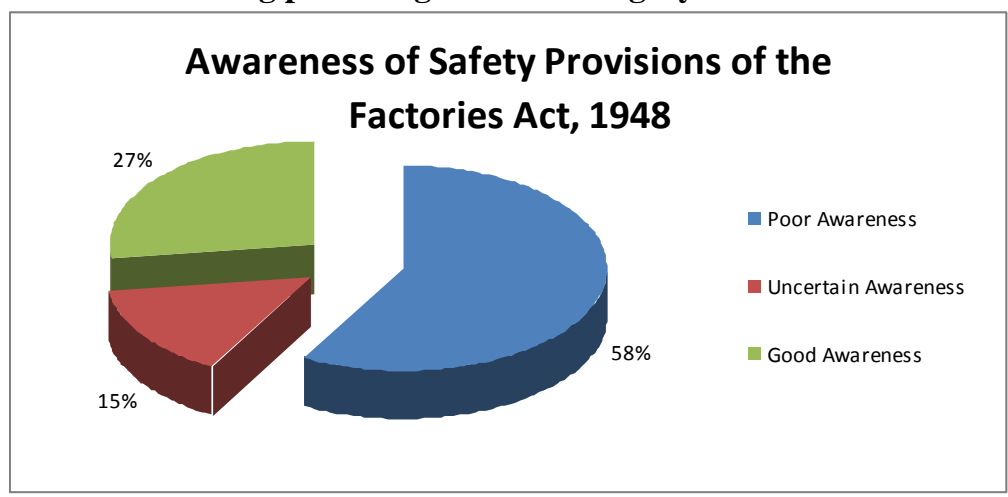

Interpretation of above Data representations

The above table shows that out of 350 responses, a total of 203 responses fall in the negative response range. On the contrary, the total no. of 95 responses fall in the positive response range. In the neutral range, there are altogether 52 responses which states that the sample employees are neither clearly aware about the 
provisions nor completely unaware about those. When computed to percentiles and studied, it can be seen that out of $100 \%$, a total of $58 \%$ responses fall in the negative response range. On the contrary, a total of $27 \%$ responses fall in the positive response range. In the neutral range, there are $15 \%$ responses. Hence, the above data clearly interprets that the AWARENESS about the various Safety Provisions of the Factories Act, 1948 among the sample employees is overall Poor.

\section{c. Awareness of Welfare measures in the Factories Act, 1948 amongst the sample employees}

The questionnaire that was used to collect the primary data consisted of total 7 questions that aimed to explore the Awareness of Welfare measures in the Factories Act, 1948 amongst the sample employees. Each question had 3 responses marked with Nos. 1 to 3 that explain the level of awareness in the ascending order from Poor [1] to Neutral [2] to Good [3]. 'Poor' responses indicate that the Awareness is INADEQUATE. 'Neutral' responses indicate that the Awareness is doubtful and uncertain. 'Good' responses indicate that the Awareness is ADEQUATE.

Tabular column Representation of the collected Data

\begin{tabular}{|l|c|c|}
\hline Awareness of Welfare measures in the Factories Act, 1948 & No. of Responses & Percentage \\
\hline $\begin{array}{l}\text { POOR AWARENESS } \\
\text { Negative Response, [=1 in LIKERT 3-point Scale] }\end{array}$ & 170 & $49 \%$ \\
\hline $\begin{array}{l}\text { UNCERTAIN AWARENESS } \\
\text { Neutral Response, [=2 in LIKERT 3-point Scale] }\end{array}$ & 40 & $11 \%$ \\
\hline $\begin{array}{l}\text { GOOD AWARENESS } \\
\text { Positive Response, [=3 in LIKERT 3-point Scale] }\end{array}$ & 140 & $40 \%$ \\
\hline TOTAL & $\mathbf{3 5 0}$ & $\mathbf{1 0 0 \%}$ \\
\hline
\end{tabular}

Bar Graph Representation based on Actual no. of responses

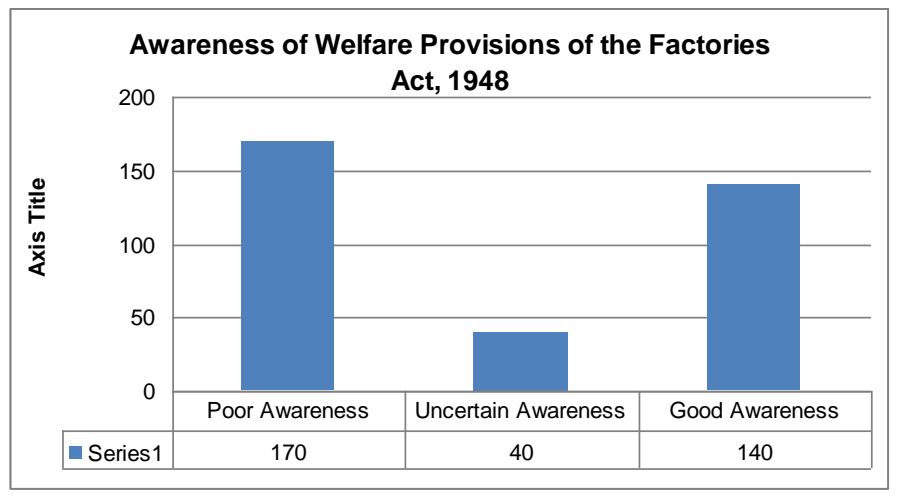

Pie Diagram Representation showing percentage in each category

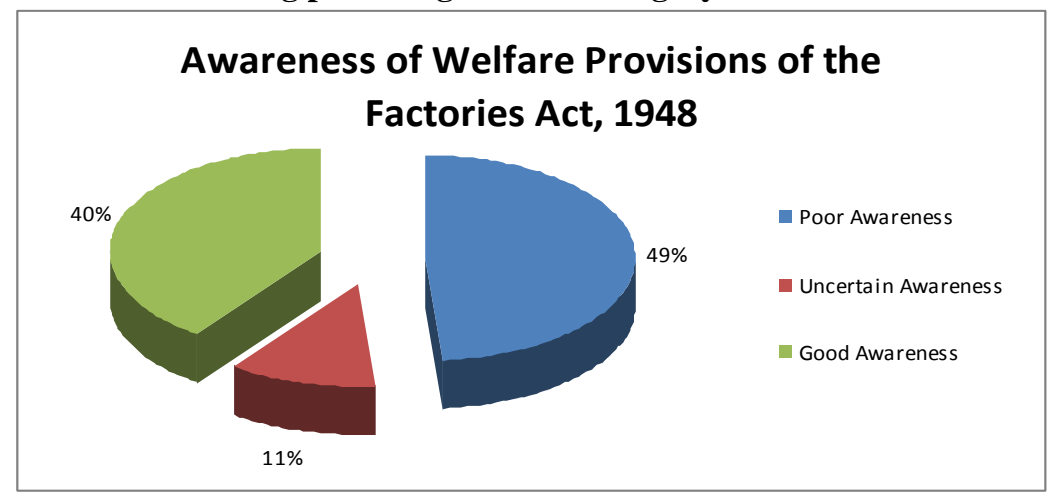

Interpretation of above Data representations

The above table shows that out of 350 responses, a total of 170 responses fall in the negative response range. On the contrary, the total no. of 140 responses fall in the positive response range. In the neutral range, there are altogether 40 responses which states that the sample employees are neither clearly aware about the 
provisions nor completely unaware about those. When computed to percentiles and studied, it can be seen that out of $100 \%$, a total of $49 \%$ responses fall in the negative response range. On the contrary, a total of $40 \%$ responses fall in the positive response range. In the neutral range, there are $11 \%$ responses. Hence, the above data clearly interprets that the AWARENESS about the various Welfare Provisions of the Factories Act, 1948 among the sample employees is overall Poor.

\section{d. Level of satisfaction of Health measures in the Factories Act, 1948 amongst the sample employees}

The questionnaire that was used to collect the primary data consisted of total 7 questions that aimed to explore the Level of Satisfaction of Health measures in the Factories Act, 1948 amongst the sample employees. Each question had 3 responses marked with Nos.1 to 3 that explain the level of Level of Satisfaction in the ascending order from Poor [1] to Neutral [2] to Good [3]. 'Poor' responses indicate that the Level of Satisfaction is INADEQUATE. 'Neutral' responses indicate that the Level of Satisfaction is doubtful and uncertain. 'Good' responses indicate that the Level of Satisfaction is ADEQUATE.

Tabular column Representation of the collected Data

\begin{tabular}{|l|c|c|}
\hline $\begin{array}{l}\text { Level of Satisfaction of Health measures in the Factories Act, } \\
\mathbf{1 9 4 8}\end{array}$ & No. of Responses & Percentage \\
\hline $\begin{array}{l}\text { POOR LEVEL OF SATISFACTION } \\
\text { Negative Response, [=1 in LIKERT 3-point Scale] }\end{array}$ & 60 & $17 \%$ \\
\hline $\begin{array}{l}\text { UNCERTAIN LEVEL OF SATISFACTION } \\
\text { Neutral Response, [=2 in LIKERT 3-point Scale] }\end{array}$ & 20 & $6 \%$ \\
\hline $\begin{array}{l}\text { GOOD LEVEL OF SATISFACTION } \\
\text { Positive Response, [=3 in LIKERT 3-point Scale] }\end{array}$ & 270 & $77 \%$ \\
\hline TOTAL & $\mathbf{3 5 0}$ & $\mathbf{1 0 0 \%}$ \\
\hline
\end{tabular}

Bar Graph Representation based on Actual no. of responses

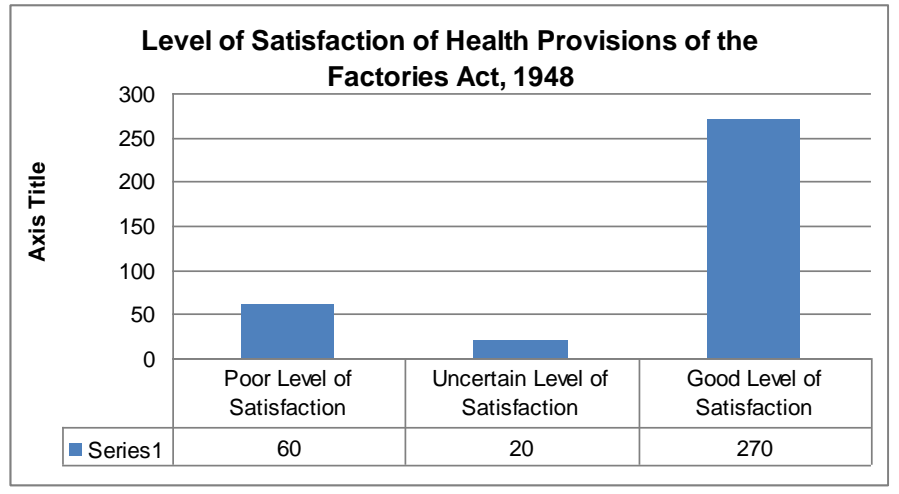

Pie Diagram Representation showing percentage in each category

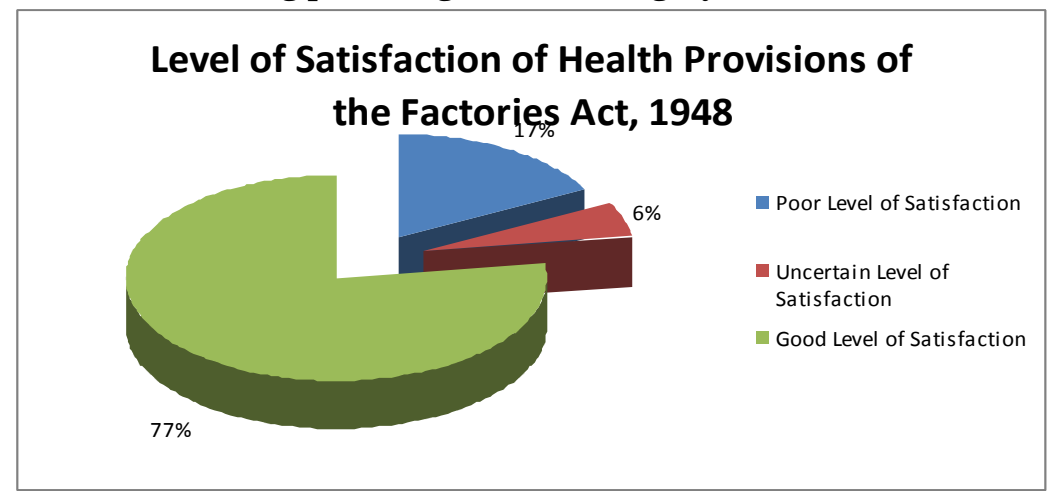

\section{Interpretation of above Data representations}

The above table shows that out of 350 responses, a total of 60 responses fall in the negative response range. On the contrary, the total no. of 270 responses fall in the positive response range. In the neutral range, there are altogether 20 responses which states that the sample employees are neither clearly aware about the provisions nor completely unaware about those. When computed to percentiles and studied, it can be seen that out of $100 \%$, a total of $17 \%$ responses fall in the negative response range. On the contrary, a total of $77 \%$ 
responses fall in the positive response range. In the neutral range, there are $6 \%$ responses. Hence, the above data clearly interprets that the LEVEL OF SATISFACTION about the various Health Provisions of the Factories Act, 1948 among the sample employees is overall Good.

\section{e. Level of satisfaction of Safety measures in the Factories Act, 1948 amongst the sample employees}

The questionnaire that was used to collect the primary data consisted of total 7 questions that aimed to explore the Level of Satisfaction of Safety measures in the Factories Act, 1948 amongst the sample employees. Each question had 3 responses marked with Nos. 1 to 3 that explain the level of Level of Satisfaction in the ascending order from Poor [1] to Neutral [2] to Good [3]. 'Poor' responses indicate that the Level of Satisfaction is INADEQUATE. 'Neutral' responses indicate that the Level of Satisfaction is doubtful and uncertain. 'Good' responses indicate that the Level of Satisfaction is ADEQUATE.

Tabular column Representation of the collected Data

\begin{tabular}{|l|c|c|}
\hline $\begin{array}{l}\text { Level of Satisfaction of Safety measures in the Factories Act, } \\
\mathbf{1 9 4 8}\end{array}$ & No. of Responses & Percentage \\
\hline $\begin{array}{l}\text { POOR LEVEL OF SATISFACTION } \\
\text { Negative Response, [=1 in LIKERT 3-point Scale] }\end{array}$ & 105 & $30 \%$ \\
\hline $\begin{array}{l}\text { UNCERTAIN LEVEL OF SATISFACTION } \\
\text { Neutral Response, [=2 in LIKERT 3-point Scale] }\end{array}$ & 24 & $7 \%$ \\
\hline $\begin{array}{l}\text { GOOD LEVEL OF SATISFACTION } \\
\text { Positive Response, [=3 in LIKERT 3-point Scale] }\end{array}$ & 221 & $63 \%$ \\
\hline TOTAL & $\mathbf{3 5 0}$ & $\mathbf{1 0 0 \%}$ \\
\hline
\end{tabular}

Bar Graph Representation based on Actual no. of responses

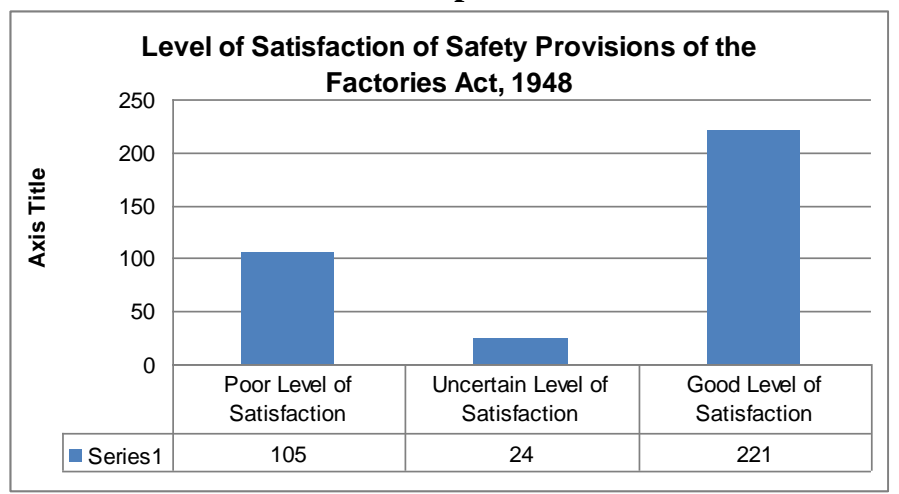

Pie Diagram Representation showing percentage in each category

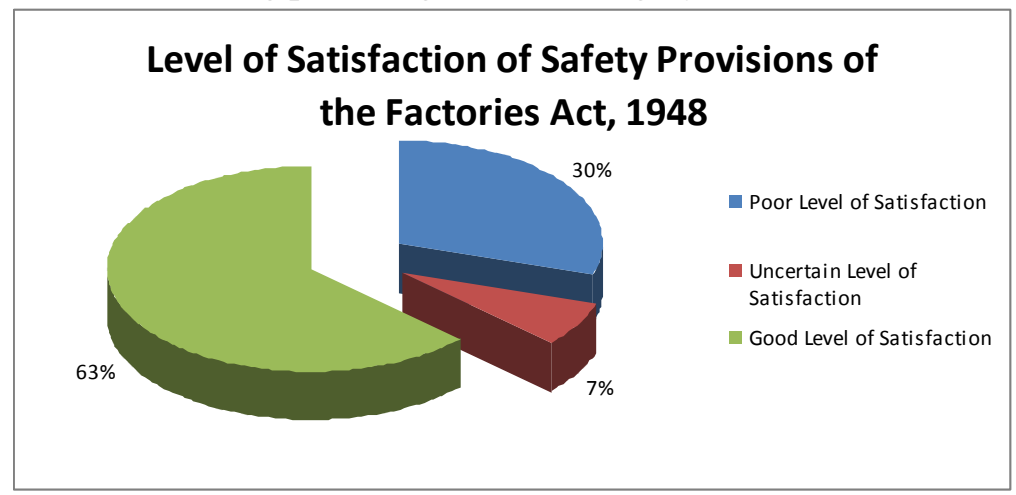

\section{Interpretation of above Data representations}

The above table shows that out of 350 responses, a total of 105 responses fall in the negative response range. On the contrary, the total no. of 221 responses fall in the positive response range. In the neutral range, there are altogether 24 responses which states that the sample employees are neither clearly aware about the provisions nor completely unaware about those. When computed to percentiles and studied, it can be seen that out of $100 \%$, a total of $30 \%$ responses fall in the negative response range. On the contrary, a total of $63 \%$ responses fall in the positive response range. In the neutral range, there are $7 \%$ responses. Hence, the above data 
clearly interprets that the LEVEL OF SATISFACTION about the various Safety Provisions of the Factories Act, 1948 among the sample employees is overall Good.

\section{f. Level of satisfaction of Welfare measures in the Factories Act, 1948 amongst the sample employees}

The questionnaire that was used to collect the primary data consisted of total 7 questions that aimed to explore the Level of Satisfaction of Welfare measures in the Factories Act, 1948 amongst the sample employees. Each question had 3 responses marked with Nos. 1 to 3 that explain the level of Level of Satisfaction in the ascending order from Poor [1] to Neutral [2] to Good [3]. 'Poor' responses indicate that the Level of Satisfaction is INADEQUATE. 'Neutral' responses indicate that the Level of Satisfaction is doubtful and uncertain. 'Good' responses indicate that the Level of Satisfaction is ADEQUATE.

Tabular column Representation of the collected Data

\begin{tabular}{|l|c|c|}
\hline $\begin{array}{l}\text { Level of Satisfaction of Welfare measures in the Factories Act, } \\
\mathbf{1 9 4 8}\end{array}$ & No. of Responses & Percentage \\
\hline $\begin{array}{l}\text { POOR LEVEL OF SATISFACTION } \\
\text { Negative Response, [=1 in LIKERT 3-point Scale] }\end{array}$ & 35 & $10 \%$ \\
\hline $\begin{array}{l}\text { UNCERTAIN LEVEL OF SATISFACTION } \\
\text { Neutral Response, [=2 in LIKERT 3-point Scale] }\end{array}$ & 14 & $4 \%$ \\
\hline $\begin{array}{l}\text { GOOD LEVEL OF SATISFACTION } \\
\text { Positive Response, [=3 in LIKERT 3-point Scale] }\end{array}$ & 301 & $86 \%$ \\
\hline TOTAL & $\mathbf{3 5 0}$ & $\mathbf{1 0 0 \%}$ \\
\hline
\end{tabular}

Bar Graph Representation based on Actual no. of responses

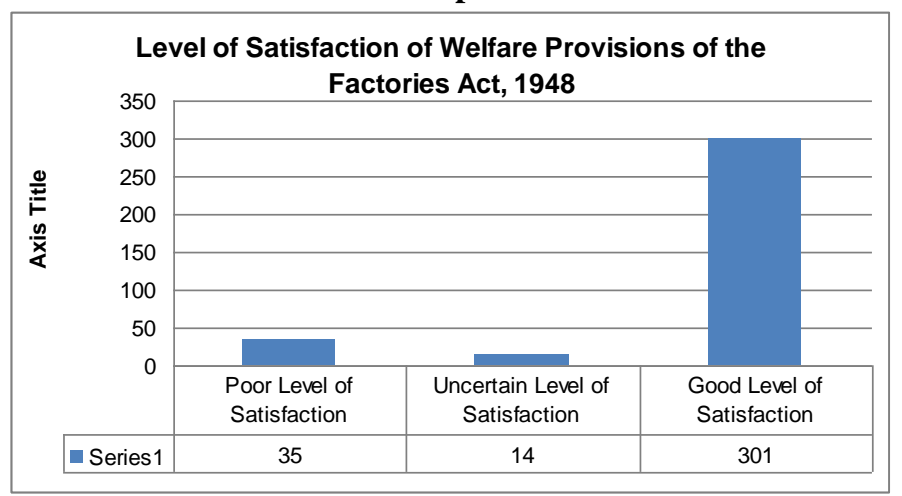

Pie Diagram Representation showing percentage in each category

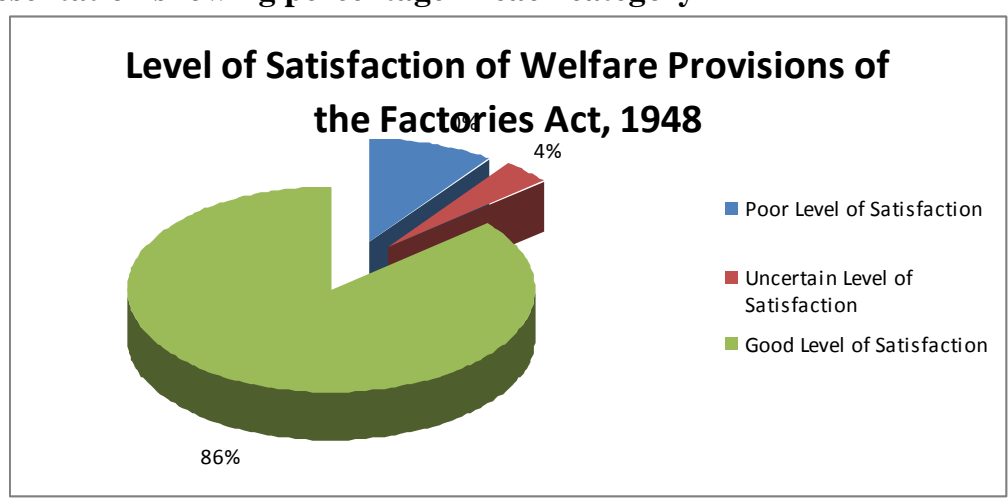

Interpretation of above Data representations

The above table shows that out of 350 responses, a total of 35 responses fall in the negative response range. On the contrary, the total no. of 301 responses fall in the positive response range. In the neutral range, there are altogether 14 responses which states that the sample employees are neither clearly aware about the provisions nor completely unaware about those. When computed to percentiles and studied, it can be seen that out of $100 \%$, a total of $10 \%$ responses fall in the negative response range. On the contrary, a total of $86 \%$ responses fall in the positive response range. In the neutral range, there are $4 \%$ responses. Hence, the above data clearly interprets that the LEVEL OF SATISFACTION about the various Welfare Provisions of the Factories Act, 1948 among the sample employees is overall Good. 


\section{Limitation of the Study}

Few of the respondents hesitated to give the correct information. Few respondents hesitated to give opinion against their management. The period of the study was limited. The validity of the study depends up on the reliability of the primary data. The research has been done in only one organization and also has focused only the lower class of employees. The results of the research although valid for the class of employees considered and for the type of industry and the type of company, the results may not be fully valid for the country overall. Therefore, for further research, it is suggested to involve more no. of companies covering all the regions in the country to all the classes of employees to which the Factories Act, 1948 apply for to make the results more optimum and valid.

\section{Conclusion}

Our research study conclude that the employees at the Penna Cements Industries Limited are not very much aware about the various provisions stated in the Factories act pertaining to the Labour viz. Health, Safety and Welfare. They are not having adequate insight to the conditions that has to be provided by the organization to them in respect to the above provisions. This is mainly because of the complicated form of text and conditions as stipulated in the factories act, 1948. The labourers are not very enthusiastic to even know the details of the provisions when they are explained. The predominally existing mindset is that there is no direct monetary gain to them even if they are well versed with these provisions. They are more keen to know the details of those acts that will affect their monetary compensation and work hour related provisions like Provident Fund Contributions, Maternity Benefit act etc.

Regarding the employees satisfaction levels, the score is very positive in comparison to the Awareness levels. By the way of this, it can be concluded that management of PCIL is doing an exceptional job in providing the facilities to its employees even though the employees are not very aware of their rights with respect to Factories Act, 1948.

It is humbly requested to management to take initiatives to educate its labourers the provisions of the Factories Act, 1948 and the management's costs and initiatives to comply with those. By doing this, the employees would be more loyal and content with the management which will have indirect effect on the employee's productivity and would reduce the employee turnover which will all contribute to an extent to improve the organizational effectiveness.

[1]. http://www.ibef.org/industry/cement-india.aspx

[2]. Agarwala (2004). From =Work to Welfare: The State and Informal Workers 'Organizations in India. American Political Science Association Annual Meeting, Chicago, Illinois

[3]. Frieda Fuchs(2005). The Effects of Protective Labor Legislation on Women's Wages and Welfare: Lessons from Britain and France. Journal of Politics \& Society December 2005 vol. 33 no. 4 595-636

[4]. John (2004). Social Security and Labour Welfare with Special Reference to Construction Workers in Kerala. Kerala Research Program on Local Level Development, paper no 65. Kwong-leung Tang

[5]. Chau-kiu Cheung (2007). Program Effectiveness in Activating Welfare Recipients to Work: The Case of Hong Kong. Social Policy \& Administration ISSN 0144-5596 Vol. 41, No. 7

[6]. Mishra \& Bhagat (2007). Principles for successful implementation of labor welfare activities from policy theory to functional theory. http://www.tesionline.com/intl/indepth.jsp?id=575 Sabarirajan

[7]. Meharajan \& Arun (2010). A study on the various welfare measures and their impact on QWL provided by the Textile Mills with reference to Salem District, Tamil Nadu, India. Asian journal of management research vol ISSN 2229 _ 3795 Padhi P K._Labour and Industrial Laws_, 4th edition. PHI Learning Private Limited New Delhi.

[8]. http://www.icgujarat.gov.in

[9]. Study Material on 'Industry, Labour \& General Laws, Module II, Paper 7' The Institute of Company Secretaries of India

[10]. 'Report of the Working Group on Labour Laws and Other Labour Regulations', Govt. of India, Planning Commission, New Delhi

[11]. Moorti M. B. "Principal of Laour Welfare, Gupta Brothers" Vishakhapattanam, A.P.

[12]. K. N. Vaid, "Labur welfare in India", Shri Ram centre for industrial relation". New Delhi.

[13]. I. L. O. S Second Report on Asia Regional Conference 1947.

[14]. The committee on labour welfare (C. L. W.), "Concept and scope of Labour welfare", Ministry, Employment \& Rehabilitation", New Delhi. (1969).

[15]. Charles Nobles, (1997) "A political History of the American welfare Stars".

[16]. Beodhar Puneskar - Labour Welfare Trade Union, Shankar (1992) Unionism \& Industrial Relation - Bombay Himalaya Publishing

[17]. Gatena R.C - Labour problems \& Social Welfare (Nalt \& Co., Meerut 1974)

[18]. Jaiswal S.L - The public sector in India - S. Chand \& Co., Ltd, Ram Nagar, New Delhi., 1981.

[19]. Kothari M - A Study on Industrial Law - Asia Publishing House, New Delhi 1968.

[20]. Mamoria C.B \& Deshi S.L - Labour Problems and Social Welfare in India. Kitab Mahal Pvt. Ltd., Bombay 1986.

[21]. Mamoria C.B - Personnel Management

[22]. Moorthy M.V (1969) - Report of Committee on labour Welfare.

[23]. Moorthy M.V (1981) Principle of Labour Welfare, new Delhi, Oxford and IBH

[24]. Moorthy N.V - principles of Labour Welfare - Gupta bros, Visakapattanam, 1968.

[25]. Report - Government of India - Report on the National Commission on Labour New Delhi - Ministry of Labour - Employment \& Relationship. 